\title{
Investigating the Social Functions of Code-Switching in Amarbail by Umera Ahmed
}

\author{
Aisha Naseem ${ }^{1}$, Qamar Khushi ${ }^{2}$ \& Hafiz Muhammad Qasim ${ }^{3}$ \\ ${ }^{1}$ M Phil Scholar, Department of English, BZ University, Multan, Pakistan \\ ${ }^{2}$ Assistant Professor, Department of English, BZ University, Multan, Pakistan \\ ${ }^{3}$ Lecturer, Department of Applied Linguistics, Govt. College University, Faisalabad, Pakistan \\ Correspondence: Dr. Hafiz Muhammad Qasim, Department of Applied Linguistics, Govt. College University, \\ Faisalabad, Pakistan. E-mail: m_qasim@hotmail.com
}

Received: February 2, 2019 Accepted: March 10, 2019 Online Published: April 20, 2019

doi:10.5539/ijel.v9n3p164 URL: https://doi.org/10.5539/ijel.v9n3p164

\begin{abstract}
The present study attempts to investigate the social functions performed by English code-switching in an Urdu novel, Amarbail, written by Umera Ahmad. The focus of the study is to examine how the societal norms and patterns of a contextual society are externalized in the selected novel through code-switching phenomenon. The study has a pragmatic stylistic focus and qualitative method has been utilized to describe the social functions of code-switching in the selected novel. The data have been selected by employing handpick non-random sampling and insights have been taken mainly from Myers-Scotton, and Albakray and Hancock for the analysis of data. The results reveal that the code-switching is a deliberate literary device exploited by the author to show the sociolinguistic norms of the target society. The main social functions performed by English code-switching in Amarbail are i) depiction of power relations, ii) construction of fluid identities, iii) acculturation and iv) maintaining class difference. The study concludes that code-switching in a literary text is a multipurpose phenomenon which not only symbolizes the societal norms of its contextual society but also displays the writer's artistic and creative aptitude. It is hoped that the bilingual writers and researchers would find results of this analysis opportune and beneficial.
\end{abstract}

Keywords: social functions, code-switching, bilinguals, socio-pragmatic, identity

\section{Introduction}

Code-switching is a language contact phenomenon which generally refers to the linguistic behavior of a bilingual speaker who consciously or subconsciously shifts from speaking one language to another, usually in response to factors associated with the particular social situation. According to Sebba (2012), linguistic behavior of bilinguals has attracted the attention of many sociolinguists, psycholinguists and descriptive linguists, which have resulted in the formulation of numerous theories and principles for this phenomenon. However, most of them pertain to spoken data. The present study, instead of exploring aspects of code-switching with reference to spoken data tries to grasp this phenomenon in written literary texts. Code-switching in literary texts is a relatively a more significant phenomenon as it is practiced on an entirely conscious level (Bakhtin, 1981; Lipsiki, 1982) and to achieve special motives (Myers-Scotton, 1993; 1998).

The main intent of this study is to analyze the social functions of literary code-switching in an Urdu novel, Amarbail. The study has a pragmatic stylistic focus, and to cater it adequately, the topic of code-switching has been approached from a sociolinguistic perspective. Sociolinguistics approach grasps code-switching primarily as a discourse phenomenon which not only helps to understand social meanings created through the practice of code-switching, but also externalizes the societal norms and conventions associated with this phenomenon (Myers-Scotton, 1998).The study attempts to explore the social and psychological associations attached with English code-switching in the target society and examines how the author of Amarbail represented these connections in the novel under study.

Previously, code-switching in literary works have been studied between Spanish-English (Jonsson, 2005; Bishop, 2006), African-English (Larsson, 2007; Bandia, 1996), Chinese-English (Hana Kang, 2008; Gao, 2005), 
Arabic-English (Albakray\& Hancock, 2008) but Urdu-English code-switching has rarely been studied in literary texts. So, exploring Urdu-English code-switching in Ahmed's novel is an attempt to fill this gap.

The main research question of the present study is:

How does the author externalize the societal norms and patterns of the contextual society through English code-switching in Amarbail?

\section{Literature Review}

The definition of code-switching given by Grosjean (1982) serves as a model in the present research as it not only adequately describes the phenomenon of code-switching, but also differentiates it from code mixing. He says:

"Code-switching is the alternation in the use of two languages (or even more) in the same discourse. The switch can happen within words, clauses, or sentences. However, there is only a switch in the language, not an integration of the word, clause or sentence into the other language" (p. 147).

So, code-switching should never be intermingled with code mixing, as code-switching is the switch of a word, clause or sentence which depicts the competent and conscious behavior of a bilingual. On the contrary, code mixing shows the interference of one language into another and it symbolizes the incompetency and unintentionality of a bilingual speaker or writer.

\subsection{Main Approaches of Code-Switching}

To explore the phenomenon of code-switching in a society, conversations, text, or in any other discourse, scholars formulated three main approaches which are given below:

- Grammatical or syntactic approach

- Pragmatic or sociolinguistic approach

- Conversational analytical approach

The grammatical approach is the initial step towards analyzing code-switching which focused on linguistic constraints (free morpheme, equivalence, and size of a constituent) (Poplack, 1980). This approach mainly describes how systematically switched words can be inserted into the syntax of other language and what limitations and restrictions occur while doing so.

The next step towards the analysis of code-switching is to understand the reasons and motivations which trigger bilinguals to code switch during their conversations. For this purpose, the sociolinguistic approach was formulated. Myers-Scotton (1998), Kachru (1985), Bhatia and Retchie (2013) offered significant and revolutionary works to describe this approach. Sociolinguistic approach grasps code-switching primarily as a discourse phenomenon focusing its attention on questions such as: i) How social meaning is created through code-switching? ii) What specific discourse functions does it perform? iii) How societal norms and patterns are externalized through language?

After the emergence of two approaches mentioned above, Auer (1984) emphasized that in order to explore the diversity of language alteration phenomenon, it is also necessary to take the conversational structure into account. So, there must be another approach which he named as Conversational Analytical Approach. He argued that this approach could explicate other realities related to code-switching like turn-taking, prosodic marking, defensive or turn internal code-switching and change of participant constellation.

The present study mainly employs the sociolinguistic approach to investigate the selected data as it seems to be the best possible way of describing socio-pragmatic functions of code-switching in the selected novel's narratives which try to represent the sociolinguistic norms of the Pakistani society.

\subsection{Socio-Pragmatic Functions of Code-Switching in Literature}

Sebba (2012) opines that during the last few years, the written aspect of code-switching has received an eminent consideration by the researchers. As a result, a number of researches related to functions of Code-Switching in literary texts have emerged on the horizon of the research world. The following section deals with the previous works on code-switching, focusing on the social reasons and purposes that trigger writers to switch from one language to another. These researches adequately externalized the social motivations for which this phenomenon is practiced in the literary texts. 


\subsubsection{Identity Construction}

Identity construction is that distinct function of literary code-switching, which is the implied purpose of almost all writers (Myers-Scotton, 2006; Jonsson, 2005; Gao, 2005; Wells, 2011). Whenever the new language is inserted in the dominant language of texts, it automatically indicates the new or preferably the true identity of either writer or the people/strata of the contextual society.

Jonsson (2005) believes that identity is fluid, constantly being constructed and reconstructed, hence along with fixed identities like ethnicity, heritage, and traditional norms, code-switching also constructs fluid identities like modernity, sophistication, and well-education. In this regard, Gao's (2005) work is significant. He identifies six different social fluid identities that are fabricated through the switching of English in Chinese-English bilingual advertising.

\subsubsection{Construction of Power Relations}

Constructing power relations is another main function of code-switching in literature as Wardhaugh (2006, p. 103) declares that code choice is "a form of political expression, a move either to resist some power, or to gain power, or to express solidarity".

In this respect, Porter's (2005) work is noteworthy because he not only describes the empowering role of code-switching in Irish songs but also proves its resisting power. He points out, as Irish was in competition for status within a colonial context that is why the use of Irish language was circumscribed by law. He verifies that the introduction of even a few Irish words into these songs which have been mainly written in English, has the ability to fracture the authority of the dominant language and producing new and enduring identity. Porter (2005) also looks at the insertion of Latin words in the same songs with empowering angle. He notes in this regard, that their usage is the result of prestige and power adhered to this privileged language which is taken as the signifier of education. The present research also validates the same concepts in the context of Pakistani culture.

Myers-Scotton (2006) points out:

"Code-switching can help the educated elite of any nation to establish and maintain what we can call the elite closure. Not just their repertoires, but also specific patterns of language separate these elites from other groups and especially, from the common people" (p. 73).

She opines that the phenomenon of the elite closure is available everywhere, but the elite closure maintained through the code-switching of powerful language mostly existed in the developing nations. The elite class of such nations present themselves as different from the local people by engaging in code-switching between a strictly local language and a language with international standing. By so doing, they can maintain a difference between themselves and the local people who do not speak the elite language with the same facility. This power related concept of code-switching presented by Myers-Scotton (2006) effectively describes the functions and reasons of code-switching in Amarbail.

\subsubsection{Culture Depiction}

Culture demonstration is again an evidential function of code-switching in literary texts. Language is the main entity of any culture which not only manifests the values and norms of culture, but also itself becomes a cultural norm. So, whenever the writers switch to any language in their texts, it's obvious that they want to portray that language's culture. Therefore, the consumption of multiple languages (code-switching) by writers implies that they want to demonstrate different cultures in their writings in order to enrich their notions (Jonsso, 2005; Martin, 2005). Additionally, sometimes, they try to externalize the cultural differences through employing the technique of code-switching.

Besides culture-depiction, code-switching also performs the function of acculturation. Because whenever we adopt another language, we automatically adopt their culture as well. Szymaniak (2002) presents this concept of acculturation through code-switching while analyzing the novel, Necessary Lies, by Stachniak (2000).

\subsubsection{Nativitization of English}

Kachru (1986) opines that code-switching is also a source of nativitization of English. By incorporating native lexical items and through other strategies, bilinguals can bring nativity to the English language. Albakray and Hancock $(2008$, p. 223) present six categories which are used by bilingual writers to portray their culture in their narratives. These categories not only show the creativity and literariness of the bilingual writers, but also describe how they present the cultural and societal norms of the contextual society. The categories are as follows: 
1) Traditional honorific titles and terms of respect

2) Historical references

3) References to customs and traditions

4) Greetings and conversational formulas

5) Inter-language dialectal variation'

6) Translational transfer

These foregoing stylistic techniques will be helpful to prove the authenticity of narratives as most of them are used in the novel under study by the bilingual writer, Umera Ahmed in the form of code-switching.

\subsection{Synoptic View of the Novel, Amarbail}

In the novel, Amarbail, Ahmad has portrayed the aristocratic society of Pakistan through a love story of protagonists, Umer and Aleeza. The novel deals not only with multiple issues of Pakistani society in a very intriguing manner, but also portrays the human psychology and emotions in a very brilliant way. The novel revolves around both the upper-class protagonists (i) Aleeza - who had her complexes, her desire in life to be loved and taken care of - and (ii) Umer a powerful character with multiple shades. He is a mixture of good and evil, far from the usual perfect hero normally painted in Pakistani novels. He is well aware of his own weaknesses, and that awareness of him is what made him sacrifice his love. Through the character of Aleeza, Ahmad portrays the psychology of the children of broken family belonging to the aristocrat class.

In short, in this novel, Ahmad exposes many hidden sides of the aristocratic class of Pakistan that how they exploit the lives of others and even the lives of the members of their family to achieve more power and fame. The novelist has used different techniques to depict the aristocratic class of Pakistan and one of them is code-switching. Her characters switch to the English language according to the requirement of the situation which gives authenticity to her narrative.

\section{Research Methodology}

The present study is based on a textual analysis of Amarbail written by Umera Ahmad. The study is qualitative in nature and hence gives the in-depth analysis of social functions of code-switching in the novel. It elucidates why and how this phenomenon is manipulated by the writer.

\subsection{Sampling Strategy}

The data for qualitative analysis have been selected by employing handpicked non-random sampling which is also called purposive sampling as it is done by having a specific purpose in mind (O'Leary, 2004).The study has focused on Grosjean's (1982) definition of code-switching which asserts that sentence, clause, phrase and even a single word can be taken as code switched instance, and hence the study has utilized all such forms of data as linguistic evidence.

\subsection{Theoretical Models}

For the analysis of data, insights have been taken from Myers-Scotton's (1993, 1998; 2006) and Albakray and Hancock's (2008) theoretical models. Following are the main propositions which lead the study:

Myers-Scotton (1993) states that (i) the code choices become intentional when they are picked from the set of opportunity (means from two or more codes), (ii) the code choices either marked or unmarked, must have some special message to denote, (iv) each linguistic choice selected by the writer/speaker must have some social or psychological associations in its contextual society and choice of it by the writers imply these contextual meanings. Moreover, this model also states that (iv) not only choices possess the speaker's intentions, but also the speakers/writers make choices with the expectation that the addressee will recognize the particular intentions behind this choice.

Albakray and Hancock (2008) present six categories which are used by bilingual writers to portray their culture in their narratives (detail given in 2.2.4). The categories presented by Albakray and Hancock (2008) have been adapted to analyze the social functions of code-switching in the novel. These categories not only show the creativity of the bilingual writers, but also describe how the writers present the societal norms of the bilingual societies in their novels by using code-switching. For the analysis of the text, these categories have been formulated by modifying the framework of Albakray and Hancock (2008). 


\section{Data Analysis}

After an intensive reading of the novel, the following social functions performed by code-switching in the novel have been extracted:

1) Acculturation

2) Construction of fluid identities

3) Depiction of power relation

4) Maintaining class difference

The insights have been taken for the analysis of the above-mentioned social functions from Myers-Scotton (2006), Kachru (1986), Lipsiki (1982), and Albakray and Hancock's (2008) theoretical models. Now, these functions are analyzed with appropriate examples selected from the novel sequentially.

\subsection{Acculturation}

The acculturative dimension of English-Urdu code-switching among Pakistani aristocratic class has been clearly shown in the novel, Amarbail. Acculturation generally is the process of adopting the cultural traits (food, musical preferences, clothing style) or social patterns (speech patterns, ethics and values) of another group, especially a dominant one. According to Marin and Kavin (2010, p. 105), "acculturation is a dynamic and multidimensional process of adaptation that occurs when distinct cultures come into sustained contact. It involves different degrees and instances of culture learning and maintenance that are contingent upon the individual, group, and environmental factor".

In Pakistan, English has become dominant, and the language of the elite class. So, the people adopt this language to get access to power and privileges. As the adoption of another language always accompanies with the absorption of its culture, that's why the Pakistani elite along with adopting the English language, is taking on the English culture as well, that results in acculturation. After the intensive reading of the novel, the following linguistic techniques of code-switching showing acculturation of the elite class of Pakistan have been extracted. These techniques are formulated by adapting the following framework of Albakray and Hancock (2008):

1) Greetings and Conversational Formulas

2) Kinship names

3) Western Values and Behaviors

\subsubsection{Greetings and Conversational Formulas}

The novelist switches to English in Amarbailwhile introducing the greeting and conversational techniques of the aristocratic characters of the novel. For example:

a) \{Hello, how are you? (hello, Aap kisay hayn), Aleeza ne keha.

O, I am fine (Mein theek houn). Umer nay halkay say sar ko nichay kia.\} (p. 17)

Translation: \{“Hello, how are you"? Aleeza said. "O, I am fine", Umer slighty bent his head.\}

b) \{ "I am sorry" (mujy afsos hy), wo halkay say minminai\} (p. 20)

Translation: \{"I am sorry", she said feebly.\}

c) \{Aleeza me tumharyliayaik gift laya hon, I swear (me qasam khata hon) aisa gift tumhain pehlay kisi nay nai dia hoga. $\}$ (p. 31)

Translation: \{Aleeza I have brought a gift for you, I swear, no one has given you such a gift before.\}

d) \{Please nano! Mera dil nahi chah raha, Believe me.\}(p. 46)

Translation: \{Please grandmother! I don't want it, believe me\}

e) \{“Thank you”,kuchdair bad Aleeza nay kaha.

“Welcome!” us nay usipursakonandaz me kaha\} (p. 48)

Translation: \{“Thank you", Aleeza said after a while. "Welcome", he said with the same soft style.\}

f) \{“Theek ha phirgood bye”, Unhoun ne sath hi baatkhatamkerdi.\} (p.137)

Translation: \{“ok good bye" he hung up the call at once.\}

The writer has used these western conversational techniques throughout the novel to show the acculturation process in the elite class of Pakistan. All the phrases like, welcome, thank you, I swear, believe me, please, hello, 
good bye and how are you, are English ways of greeting and conversation, which have been adopted by the elite class of Pakistan. Rehman (2003) opines that in Pakistan, people switch to the English language in their conversation because they want to be identified as educated, modern and sophisticated. Therefore, the writer intentionally switches to these phrases in her novel to portray the authentic picture of the aristocratic strata of Pakistan.

A noticeable point in the novel is that whenever the writer introduces the characters from the lower strata of society, she at once changes her tone and turns towards the traditional style of greeting and conversation of Pakistan, for example:

a) \{Assalam o Alaikum! Aleeza Bibi! Kisi hanaap? Issiwaqat khan samachayki tray lay keraia, us nay aatay hi Aleeza ko mukhatab kia\} (p. 15)

Translation: \{'Hi Miss Aleeza! How are you?Meanwhile the cook came with the tray of tea and spoke to Aleeza\}

b) \{“Inshalahtalah aapko ziaqa bheachalagyga sir", mulazim nay umer kay tabsaray kayjawab meinkeha.\} (p. 610)

Translation: \{"Sir you will surely like its taste as well", the servant stated on Umer's remarks.\}

The phrases, Inshalahtalahand Assalam o Alaikum are the compact greeting and conversation items of Pakistani society. They also show the religious identity of the Pakistanis, which have never been used by any aristocratic character in the whole story. Thus, by switching to English conversational terms in the novel, the writer actually connotes the acculturation in the behavior and language of the elite class of Pakistan.

\subsubsection{Kinship Terms}

The writer also uses code-switching phenomenon to represent kinship terms used by the elite class of Pakistan.

a) \{Grandpaa mein khanana hi khaonga,........,Yeh to bas Granny nay pakarkerbithaliatha.\} (p. 80)

Translation: \{I will not take lunch grandpa......its granny who insisted me to sit for a while.\}

b) \{Jab tumharypapa or uncles nay civil service join kithi to mein nay unhain bi both si nasihatain ki theen \} (p. 33)

Translation: \{when your papa and uncles had joined civil services, I advised them also $\}$

c) \{Me to foreign service join karnay $\mathrm{k}$ bad $d a d d y$ kitarha is hkarnachatahon $\}$ (p. 34)

Translation: \{After joining the civil service, I want to live lavishly like daddy\}

d) \{“ye Papa or Mammy kakamra hay" us nay aik or kamray ka darwaza kholtay howay usay kaha\} (p. 66)

Translation: \{this is papa and mammy "s room" he said to her while opening another door\}

In Pakistani culture, great importance is given to the kinship structure, and there are a lot of terms used to refer to kinship relations in this society. But in Amarbail, the writer employs specific western kinship terms to demonstrate the linguistic behaviour of the elite class of Pakistan, who habitually use these English terms in their daily lives. The elite class of Pakistan use English kinship terms like Papa, Mummy, Granny, Daddy, Grandpa and Uncle because they try to westernize themselves and want to show their English identity. Moreover, they also use these terms to maintain a distance between them and the common people of society, who are strictly adhered to the cultural kinship terms like Chacha (uncle), Abu (father), Ami (mother),Phopho (aunt), Dada (paternal grandfather), Dadi (paternal grandmother), Nana (maternal grandfather).

However, there is only one exceptional case. The writer also employs the word 'Nano' for grandmother along with Granny which shows the cultural hybridity of this class. It also denotes that the culture of this class is the amalgamation of two cultures, which creates the split in their personalities. As Umer says to Aleeza, "We are lost generation with paradoxes in our lives. We are enjoying the lifestyle which is not affordable by ninety-eight percent of our country's population but still, we are deprived of true relations (p. 279). This deprivation of the elite class is due to the adoption of the English culture, where relations are not as important as in Pakistani culture (the diversity of linguistic terms for kin relations in Pakistan is the proof of the strength of family structure).

So, the insertion of the English kinship terms in the Urdu novel is another example of acculturation of the elite class displayed by the tool of code-switching. 


\subsubsection{Western Values and Behaviors}

The writer employs code-switching of English in Amarbail to reveal the authentic sociolinguistic patterns and values of the elite class of Pakistan. But along with linguistic choices, she also presents some extra-linguistic evidence which show the acculturation in the behaviors of the aristocratic class and which solidify the writer's notion as well. For example:

a) \{Christy kehanhay, ....... Christy! Us nay buland awaz mein pukara. "mein nay tumhaybohatbohat miss kia",Us nay us sufaidbili say younkehajisaywo is kibaat sun rahi thee.\} (p. 14)

Translation: \{“where is Christy....... Christy”! she called her loudly. "I miss you very very much", she said to white cat in such a way as if she was listening to her words

Example (a) shows, by inserting the term Christy for Aleeza's cat, the writer tries to portray the English culture of the elite class of Pakistan.Christy is an English name. The way Aleeza treats her pet is analogous to the way the English or Western people keep their pets. These examples corroborate the idea of Szymaniak (2002) that the practice of code-switching becomes the reason of acculturation as adopting other's language will surely change one's living style and behavior accordingly.

b) \{“Tum modeling kernaylagi ho"? Umer nay Shanza say keha

"Professionally nahi bus adventure kay tour per" ....\} (p. 220)

Translation: \{do you start modeling"? Umer asked Shanza. "not professionally but for adventure" ......she replied $\}$

c) $\{$ Wo drink kartatha, us ki both sigirl friendstheen....... (p. 183)

Translation: \{he used to drink, he had many girlfriends....

The code-switching instances present in examples (b) and (c) show the behavioral values of the elite class of Pakistan. These values are akin to the western culture. In Pakistan's culture generally, modeling is not considered a respectable job. So, the girls of the noble families never do this. But for the girls of Pakistan's aristocratic class, it is an adventure and a leisure activity. Whereas example (d) describes the activity of one of the characters that he used to 'drink' and used to have 'girl friends', both of these activities are considered normal in the English culture, but in Pakistani culture, both of them are prohibited. The novelist switches to the English terms, modeling, drink and girlfriends, to show the behavioral traits of the elite class of Pakistan, which have now become the class symbol of the elite class. So, code-switching phenomenon in Amarbail is employed to portray the societal ways and behaviors of the aristocratic class of Pakistan as well.

d) \{Happy birthday, Aleeza nay usaymubarak bad di\} (p. 403)

Translation: \{“Happy birthday", Aleeza congratulated him.\}

e) \{Ladies club ny Bourbon me musical eveningskaintazamkia hay...tum chalogiwahan? Do musical evenings hainwahan per.... AsadAmanat Ali aurTahira Sayed kay sath”\} (p. 378)

Translation: \{ladies club has arranged musical evenings in Bourbon...will you go there? There are two musical evenings...one with AsadAmanat Ali and the other with Tahira Sayed.\}

The examples (d) and (e) contain such switched words that describe the western ceremonies like Birthday celebrations and Musical evenings, which have become the part of Pakistan's elite class life as well. These are neither the Islamic nor the traditional ceremonies of Pakistani society rather these are the production of the English culture that has been transferred to Pakistan. In the whole novel, the writer mentions these shows and parties many times with relation to the elite class, but never mentions the original Pakistani festivals like Eid-ul-Fitr, Eid-ul-Azha etc. It is because the elite class gives more importance to the western ceremonies like birthday, musical evenings and dinner parties instead of traditional festivals of Pakistan. As the writer has to portray this class so she uses these words which effectively depict the societal norms of this class.

In short, the writer of Amarbail has used literary code-switching as a tool to present the real picture of the culture of the aristocratic class. By employing code-switching, she vividly portrays the life style of this class and the linguistic choices they make to communicate with one another, which could not have been so realistically presented if the code-switching phenomenon had not been employed.

\subsection{Construction of Fluid Identity}

The code-switching also performs the function of identity construction in the novel. Gao (2005) states that fixed identities are those identities which are not easily subject to change like ethnicity, heritage, gender, or race. 
Whereas, fluid identities are those which are constantly constructed and reconstructed like modernity, sophistication and good education.

In Amarbail, the writer constructs fluid identities through the practice of code-switching phenomenon like powerful, sophisticated, educated, superior and talented. She depicts how the English language is used in the Pakistani society to construct such identities.

a) \{“Mind your own business, meray profession ki akhlaqiat sikhanay ki koshish mat karo......And don't try to poke your nose into my affairs."(Abass says to Aleeza)\} (p. 371)

Translation: \{"Mind your own business, don't try to teach me the protocols of my profession And don't try to poke your nose into my affairs." (Abass says to Aleeza)\}

b) \{“Enough is enough, now I'll pay him in the same coin (Ab mein unhay unhiki zuban mein jawab dounga)".Umer nay phone band kerdia)\} (p. 273)

Translation: \{“Enough is enough, now I'll pay him in the same coin”, Umer hung up the call.\}

c) \{Aleeza nay baysakhtakaha, "it means that I am going to marry a heartless person".

Junaid nay bhiutni hi bysakhtagi say kaha, "on the contrary I am going to marry a girl with two hearts") (p. 537)

Translation: \{Aleeza said spontaneously, "it means that I am going to marry a heartless person". With the same whim,Junaid replied, "on the contrary, I am going to marry a girl with two hearts" $\}$.

d) \{“Jahangir se isska koi jhagrahogia hay, iss ne mujhay tafseel nahi batai laykin, they are not on talking terms now-a-days." Nano nay Aleezakojawab dia.\} (p. 11)

Translation: $\{$ He has a clash with Jahangir, he did not give me details, but they are not on talking terms now-a-days", grandmother replied to Aleeza.

In the examples cited above, different comments of all the main characters (Aleeza, Umer, Abbas, Nano and Junaid) are given, that show the linguistic patterns of the members of the elite class of Pakistan, they use during their everyday conversations. The linguistic choices they made differentiate them from the common people of the society. As Myers-Scotton (2006) states:

Code-switching can help educated elite of any nation to establish and maintain what we can call elite closure. Not just their repertoires but also specific patterns of language separate these elites from other groups and especially from the common people (p. 74).

The examples show that English code-switching is available in daily life conversation of the young and old people of this class. They employ English to a great extent in order to be identified as educated, modern, cultured and elite people. Rehman (2003) and Kachru (2005) validate that these identities are also attached to the English language along with power in Pakistan. So, the writer frequently switches to English in Amarbail because she wants to construct the real identity of this class of Pakistan and also to validate her words.

The linguistic choices of grandmother \{ "they are not on talking terms now-a-days", example (d)\} are especially unusual because, in Pakistani society, the grandparents scarcely know English rather they mostly communicate in the vernacular languages. But the grandparents portrayed in Amarbail, habitually switch to English which asserts their identity as educated, cultured and elite people.

Examples (a) and (b) show that the members of the elite class of Pakistan have such a good command over the English language, that they frequently insert English proverbs into their normal conversations. Hence, their selected linguistic patterns not only discriminate them from the common public, but also reveal their vast knowledge and competency in the English language. Moreover, all these examples validate the idea that English is the language of the elite class in Pakistan, to which different positive stereotypes are attached. The common people of Pakistani society who want to be identified by the labels or identities (like educated, cultured, modern and elite) try to increase the usage of English language in their conversations and this has become the linguistic norm of this society (Jabeen\&Mahmood, 2011).

\subsection{Empowerment/Dominance}

As mentioned earlier, Amarbail depicts the elite class of Pakistan, who frequently use the English code-switching in order to assert their power and dominance over others through this language of power along with other ways. Myers-Scotton (2009) gives the concept of elite closure which according to her is possible because of three sociolinguistic universals: 
i. Not all people in the same community speak the same linguistic varieties

ii. The linguistic varieties in use in any community are generally allocated to different situational uses.

iii. All varieties are either positively or negatively evaluated by community members, according to their use in the specific type of interaction.

Rehman (2003) validates that (i) English is the language that is positively evaluated by the people of Pakistan, ii) it is used in the domains of power like official works, for formal meetings, for interviews in higher institutions and organizations and, iii) common people generally cannot use it with ease, rather it is habitually used by either the highly educated people or people of the elite class. So, the English language is used in Pakistan to intact the elite closure, which bans the entry of the common people to the high status and prestige attained by this language of power.

Hence, the writer through her linguistic choices along with other extra linguistics resources tries to depict the elitist people's behavior, attitude and lifestyle which detach them from the common people of the society and make them dominant.

a) \{LUMS me parhraha tha mera beta... apnay batch ka sub say outstanding student tha. $\}$ (p. 386)

Translation: \{My son was studying in LUMS.....and he was the most outstanding student of his batch.\}

b) \{Tum British council jarahi ho?......... Me nay socha mein bhi aik chakar wahan ka lagaaon, kafi arsa ho gaia hay iss bar. Me British History per aik do kitabainlaynachahrahahoon.\}(p. 243)

Translation: \{Are you going to British council?........ I thought to pay a visit over there as it has been long since I visited it. I want to take some books on British History.

c) \{Abbas aiksaalkichuti lay kar England criminology ka course karnayjarahatha\} (p. 385)

Translation: \{After taking one-year leave (from his job), Abbas was going to England to do a course of criminology

In the afore-mentioned examples, the writer presents that the elite class of Pakistan has access to the best educational institutes and places where they can amply learn the powerful language of English. Whereas, the common people get education in the government institutes where not only the medium of education is Urdu but also there is the unavailability of such teachers who can teach the English language competently. Therefore, only the elite people can get all good jobs which increase the socioeconomic difference between both the classes by every passing day. The writer shows this in the novel as all the main characters have the best jobs in Pakistan. For example, Umer and Abbas are S.P. City, Jahangir Ma'az and AyazHaider are officers in the Foreign Service, Junaid is a well-known architect whereas Saliha and Aleeza are journalists of an English newspaper.

d) \{“Kia gift chahiay?" Nana ko b dilchaspimehsos hoi.

"koi bhiachicheez, Armani ka suit, Denim ki jeans, Christian Dior kighariyaphirPlayboy or Lomani $k$ perfumes." Us nay aiklambi list ginwaithi.\} (p. 29)

Translation: \{"What type of gift do you want?", grandfather got interested as well. "Anything, like Armani's suit, Denim's jean, Christian Dior's watch or Playboy or Lomani's perfumes", he presented a long list.\}

Now, this example shows their access to the branded and most expensive things, they not only know the names of all brands, but also have the economic power to buy them. But the common people of Pakistani society cannot afford these branded items even they do not know their names. So, through the switched words given in example (d) the writer wants to present their status and monetary dominance.

In short, through the practice of code-switching in Amarbail, the writer wants to depict that the English language in Pakistan is not only the means of socio-economic dominance, but also used to preserve the status quo. Moreover, it is also a source of power and exploitation in the contextual society.

\subsection{Maintaining Class Difference}

The practice of Code-Switching in Amarbail also portrays the phenomenon of class difference in the Pakistani society. By employing code-switching, the writer shows the difference between the language of the elite class and their servants or subordinates. She also depicts how through language choices, the status and class difference are maintained in the society. The following examples show the linguistic items chosen by the servants as the greeting and conversational formulas:

a) AAsslam o Alakum! AleezaBibi! Kaysihanaap? Issiwaqatkhansamachayki tray lay keraya, us nay aatay hi Aleezakomukhatabkia. 
Mein bilkultheekhounMureed baba! App kaysayhain? Is nay jawaban unka haal poocha.

Allah kashukar hay Bibi! ....... Mureed baba nay kaha\} (p. 15)

Translation: \{“Hello Madam Aleeza! How are you?Meanwhile the cook came with the tray of tea and spoke to Aleeza the moment he entered.

"I am fine, how are you Mureed baba", Aleeza asked about his health in response. "Fine by the grace of Allah", he replied\}

b) \{“inshalahtalahaapkozaiqabheeachalagayga sir”, mulazim nay umerkaytabsaraykayjawabmeinkeha\} (p. 610)

Translation: \{"Sir you will surely like its taste as well", the servant stated on Umer's remarks.\}

Now, the following examples reveal the linguistic patterns of members the elite class:

c) \{So the lady is here! (To muhtarmayehanhayn), Nana nay usaydekhtay hi kehatha.\} (p. 16)

Translation: \{"So the lady is here! Grandfather said her instantly while seeing her.\}

d) \{“He has always been handsome (who hamaysha say handsome hay)", Nano nay fakhriaandazmeinkeha.\} (p. 55)

Translation: \{"He has always been handsome", grandmother said proudly.\}

e) \{Hello, how are you? (hello, Aapkasayhayn), Aleeza ne keha.

$O$, I am fine (Mein theekhoun).Umer nay halkay say sarkonichaykia.\} (p. 17)

Translation: \{“Hello, how are you? Aleeza said. "O, I am fine",Umer slightly bent his head.\}

Examples (a), (b) and (c) index towards the language choices of the subordinate people. The intensive reading of the novel reveals that the writer never switches to the English words throughout the novel while representing the conversations of the servants and lower people. At one or two places, she adds some unmarked conventional English words in their dialogues like airport, table and shopping. Moreover, conversational phrases like 'Asslam o Alakum', 'inshalahtalah'and'Allah kashukarhayBibi' are introduced only in the chats of the lower class which show that they adhere to their cultural norms, unlike their Sahibs. On the other hand, in examples (c), (d) and (e), linguistic choices of the elite class are given. These examples depict that even the grandparents are habitual to add English words and sentences in their conversations. Moreover, a lot of examples in the novel show that these people always use western conversational formulas to greet one another like Hello! how are you? So, the linguistic behaviour of both the classes externalizes the difference between them.

f) \{“In logon kobariachitarhapatahota hay k sahib log English us waqatboltayhain jab wo koi baat in say chupanachahtayhain......is liayEnglish un kaysamnaykabhi matt bolo, behtr hay Punjabi me baatkaro...daikhokistarahkamasaanhotayhain"\} (p. 555)

Translation: \{These people know very well that their masters will speak English when they want to hide something from them.......... that's why never speak English before them, rather it's better to speak Punjabi........and see how the things become easy.\}

All the examples given above, especially (f), present the vivid demo of 'we' and 'they' code dichotomy, the idea given by Gumpers (1982) and which can be applied in many places. The linguistic behavior of both the classes presented in the novel express that elite class considers English as 'we code' and other vernacular languages as 'they code', mean the code of the lower and middle class. As positive identities like prosperity, powerful, cultured, educated and talented are attached to the English language, so the difference comes in all the domains.

Furthermore, the practice of intersentential code-switching in a conversation usually excludes the monolingual people (Lipsiki, 1982), hence by employing intersentential code-switching in her novel (as shown in c, $d$ and e), Ahmad actually wants to present the linguistic behavior of the aristocratic class which excludes the other population from their strata by employing language style which they cannot adapt. The afore-mentioned instances of the novel depict that the lower strata of society only speak Urdu language or other vernacular languages and cannot understand English. So, the code-switching practice in the novel, Amarbail indexes towards this societal norm of the contextual society very effectively.

\section{Conclusion}

The detailed analysis of Amarbail reveals that the intention of the writer to practice code-switching phenomenon in her novel is to present the societal norms and standards of the Pakistani society, especially of its elite class. The acculturation in the behavioral patterns and values of the elite class of Pakistan have been very effectively 
delineated in Amarbail by inserting names of the specific English ceremonies, values and beliefs, and specific English cultural and conversational terms. Code switched linguistic elements used in the novel have successfully signified the sociolinguistic reality of Pakistan, where the English language is the most prestigious, valued, privileged and powerful language, and where people exploit the English language to be identified as an educated, affluent, cultured and powerful individual. Moreover, the analysis has shown that code-switching is the powerful way of expressing societal and linguistic norms of any society, which cannot be properly externalized otherwise. It also proves that code-switching phenomenon practiced in the novel is not an arbitrary or futile phenomenon, but a purposeful and deliberate activity which possesses certain intentional messages the writer wants to propagate. In short, the writer of Amarbail has used code-switching as a tool to publicize the facts about the elite and aristocratic strata of Pakistan on the national level which not only validates her words, but also gives a colour of authenticity to her narrative.

\section{References}

Ahmad, U. (2008). Amarbail. Ilim-o-Irfan Publishers: Lahore.

Albakry, M., \& Hancock, P. H. (2008). Code-switching in Ahdaf Soueif 's the Map of Love. Language and Literature, 17(3), 221-234. https://doi.org/10.1177/0963947008092502

Auer, P. (1984). Bilingual Conversation. US: John Benjamin. https://doi.org/10.1075/pb.v.8

Bandia, P. (1996). Code-Switching and Code-Mixing in African Creative Writing: Some Insights for Translation Studies.

Bhatia, T. K., \& Ritchie, W. C. (2013). The Handbook of Bilingualism and Multilingualism. London: Blackwell.

Gao, L. (2005). Bilinguals' Creativity in the Use of English in China's Advertising. Somerville, MA: Cascadilla Press.

Gumperz, J. J., \& Cook-Gumperz, J. (1982). Introduction: language and the communication of social identity. In J. G. John (Ed.), Language and Social Identity. Cambridge: Cambridge University Press.

Hanna, L. (2007). Code-switching in Chinua Achebe's Novels.

Jabeen, F., Mahmood, M. A., \& Rasheed, S. (2011). An Attitudinal Study of Pakistani English. Interdisciplinary Journal of Contemporary Research in Business, 3(5), 109-119.

Jonsson, C. (2005). Code-switching in Chicano Theater: Power, Identity and Style in Three Plays. Omslag.

Kachru, B. (1986). The Alchemy of English: The Spread, Functions, and Models of Non-native Englishes. New York: Oxford press.

Kachru, B. (1996). South Asian English: Toward an Identity in Diaspora. South Asian English: Structure, Use, and Users. U.S: University of Illinois.

Kang, H. (2008). A Discourse Analysis of Code-Switching in Falling Leaves and Luoyeguigen. Ohio, 2, 9991010.

Lipski, J. M. (1982). Spanish-English Language Switching in Speech and Literature: Theories and Models. Bilingual Review, 9(3), 191-212.

Martin, H. E. (2005). Code-switching in US ethnic literature: multiple perspectives presented through multiple languages. Changing English, Studies in Culture and Education, 12(3), 403-415. https://doi.org/10.1080/13586840500347277

Myers-Scotton, C. (2009). Elite Closure as a Powerful Language Strategy: The African Case. International Journal of the Sociology of Language, 103, 149-163.

Myers-Scotton, C. (2006). How Code-switching as an Available Option Empowers Bilinguals. Along the Routes to Power: Explorations of Empowerment through Language. Germany: Mouten De Gruyter.

Myers-Scotton, C. (1998). Codes and Consequences: Choosing Linguistic Varieties. New York: Oxford University Press.

Myers-Scotton, C. (1993). Duelling Languages: Grammatical Structure in Code-switching. Oxford \& New York: Oxford University Press.

Myers-Scotton, C. (1988). Code-Switching as Indexical of Social Negotiations. In M. Heller (Ed.), Code-switching: Anthropological and Sociolinguistic Perspectives. Berlin\& New York: Mouton de Gruyter. https://doi.org/10.1515/9783110849615.151 
O’Leary, Z. (2004). The Essential Guide to Doing Research. London: Vistaar.

Porter, G. (2005). Code-switching and Empowerment in the Macaronic Irish Lyric. Käännösteoria, Ammattikieletjamonikielisyys, 35, 257-267.

Rehman, T. (2003). Language policy, multilingualism and language vitality in Pakistan.

Sebba, M. (2012). Researching and Theorizing Multilingual Texts. In S. Mark, M. Shahrzad \& J. Carla (Eds.), Language Mixing and Code-Switching in Writing: Approaches to Mixed-Language Written Discourse. New York: Roultedge. https://doi.org/10.4324/9780203136133

Sebba, M., Mahootian, S., \& Jonsson, C. (Eds.). (2012). Language Mixing and Code-Switching in Writing: Approaches to Mixed-Language Written Discourse. New York: Roultedge. https://doi.org/10.4324/9780203136133

Szymaniak, W. J. (2002). Code-switching and English Language as a Free-culture Medium: Case Study of the Novel Necessary Lies by Eva Stachniak (pp. 311-322). Cauce, Revista de FiloloRÍa y suDidáctica.

Wardhaugh, R. (1998). An Introduction to Sociolinguistics. USA: Blackwell.

Wells, M. (2011). Code-switching in the comedy of George Lopez. Journal of Applied Language Studies, 5, 6576.

\section{Copyrights}

Copyright for this article is retained by the author, with first publication rights granted to the journal.

This is an open-access article distributed under the terms and conditions of the Creative Commons Attribution license (http://creativecommons.org/licenses/by/4.0/). 